\title{
PERCEIVED PARENTING, SCHOOL CLIMATE AND POSITIVE YOUTH DEVELOPMENT: A PREDICTING MODEL
}

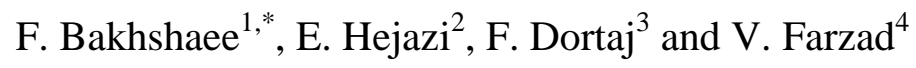 \\ ${ }^{1}$ Imam Reza International University, Mashhad, Iran \\ ${ }^{2}$ Faculty of Psychology and Educational Sciences, University of Tehran, Tehran, Iran \\ ${ }^{3}$ Faculty of Psychology and Educational Sciences, Allameh Tabataba'I University, Tehran, \\ Iran \\ ${ }^{4}$ Faculty of Psychology and Educational Sciences, Kharazmi University, Tehran, Iran
}

Published online: 15 May 2016

\begin{abstract}
Positive youth development is the ideal process of human development that includes five psychological, behavioral, and social indices as competence, connection, confidence, caring and character. The present study was conducted aiming at predicting positive youth development based on perception of parenting and perception of school climate. For this purpose, 400 female high school students of Kerman responded to the scale of parenting style perception, school climate perception, and positive youth development. The results of correlation analysis indicated a positive and significant correlation between school climate dimensions (teacher support, autonomy support and students support), and positive youth development and a positive and significant correlation between perception of parenting dimensions (parent engagement, warmth and autonomy support) and positive youth development. In addition, the results of stepwise regression indicated that parent engagement, teacher support and parent autonomy explain $40 \%$ of the changes of positive youth development.
\end{abstract}

Keywords: Positive youth development; perception of parenting; perception of school climate.

Author Correspondence, e-mail: fbakhshae@yahoo.com

doi: http://dx.doi.org/10.4314/jfas.v8i3s.253 


\section{INTRODUCTION}

Youth is one of the most important periods in individual and social life. In fact, youth period is a bridge between childhood and adulthood in which adolescents are forced to pass to find their position as a grown individual (Shaffer \& Kipp, 2013). According to Benson (1997) divided youth-related views into two main groups of "DP (Deficit Perspective)" and PYD (Positive Youth Development".

DP emphasizes confusion and conflict in the youth period and, in fact, according to this approach, adolescents should deal with describing, explaining, predicting and controlling developmental issues and problems in the youth period and the pathology of this period, while, PYD stresses on adolescents' capital, abilities and talents instead of conflict and deficits (Benson, Mannes, Pittman \& Ferber, 2004; Lerner \& Benson, 2003). Therefore, the new approach of PYD has been developed over the twenty past years emphasizing adolescents' abilities. PYD is a perspective based on positive ability, characteristics and outcomes that we want from adolescents to achieve them. This perspective is beyond DP, which focuses on adolescents' problems and deficiencies dominant over developmental, psychological, educational sciences and mental health as well as other scientific fields for years in the twentieth century (Bowers et al., 2010). The concept of growth progress in DP often includes separating individual and environment and usually the nature and education. The theories based on this approach mainly stress on the predetermined organism characteristics (Lerner, Dowing \& Anderson, 2003). Describing adolescents as individuals whom their control is difficult is, in fact, considered their abasement. This issue makes adolescents involved in negative and risky behaviors. In other words, it is extremely discomforting and disappointing that their adults describe them as individuals who makes problems for themselves and others (Lerner et al., 2005), while, PYD is based on the point that each youth has necessary capacity to be successful, developed healthily and positively. The fundamental philosophy of PYD indicates that individuals, cultures and nations should believe that humans, adolescents and the elderly are resources that have the capacity to be developed and therefore, they should not be considered as individuals who are always engaged in problems and abnormalities and need help to solve their problems (Bundick, Yeager, King, \& Damon, 2010).

PYD is conceptualized in different forms (Lerner et al., 2011). One of these models is suggested by Lerner (2004) in the form of "five Cs" and based on the theoretical and research literature of PYD (Roth \& Brooks-Gunn, 2003; Lerner, 2004; Gootman \& Scales, 2002). The 
five Cs include competence, confidence, connection, caring and character. Confidence indicates an inner sense of self-worthiness and self-efficiency. Competence shows individual's positive view to his actions in the different academic, cognitive, social and physical areas. Character indicates revering cultural and social regulations and having some criteria for right and wrong behavior and feeling (morality). Connection refers to have positive relationships with family members, school peers, and society members. The relationships that have reciprocal and result in positive changes for the parties caring or compassion shows sympathy for others and how much adolescents are affected by others' tension. These characteristics enable adolescents to take step in the adult world desirably. PYD approach with stressing adolescents' strengths and abilities believes that considering these abilities and reinforcing them can place them in the path of positive development. Finally, the thriving adolescent not only will be safe from endogenous and exogenous problems such as depression and dangerous behaviors, but also will achieve another characteristic of self-help and contribution in the family and civil society (Farruggia \& Bullen, 2010). Considering contextual factors are effective in adolescents' PYD, therefore, in the present research, POP (Perception of Parenting) and PSC (Perception OF School Climate) are analyzed as the variables effective on PYD.

Family as the most fundamental social institution along with interpersonal factors, plays a crucial role in students' positive development and preparation of them to confront life challenges. Parents, as the factor of socializing children, play an important role in satisfying their psychological needs and their positive development. Ryan and Deci (2000) in the theory of "self-determinism" regard man as an active creature with particular psychological needs, and an internal motivation to satisfy his needs and his inherent tendency to be dominant over his surrounding environment so that his wellbeing depends on satisfying three innate, basic and universal needs including autonomy (selecting deeds freely), competence (mastery over deeds) and belonging (making relation with important individuals in life and enjoying their support). The context and environment that contribute to the satisfaction of these psychological needs by their support, provides the background to achieve high psychological wellbeing in individuals (Grolnick, Deci, \& Ryan 1997).

In the theory of self-determinism, parents' effect is investigated in the three frameworks of participation parenting (a degree in which parents identify their children's favorite activities and participate in them actively), autonomy support (a degree in which parents encourage children in problem-solving and granting them the right to select and participate in decision- 
making) and warmth (expressing love, kindness, interest and satisfaction to children) have been investigated.

Chand et al. (2013) by reviewing the research literature referred to the parenting factors that are significant for the developmental outcomes of adolescents. These factors include low levels of adolescent-parents conflict (McElhaney et al., 2009), parents' warmth (Nash et al., 2005), parents' effective supervision (Kerr \& Statin, 2000) and encourage of autonomy and decision-making in adolescents (Silk et al., 2003). In addition, the results of the research conducted by West-Olatunji, Sanders, Mehta, \& Behar-horenstein (2010) indicated that parents' warmth and support of children play a crucial role in their academic achievement.

Furthermore, according to Deci and Ryan (1985), adolescents attempt to find meaning in their experiences at school, especially the need to perceive competence and relationship are among important aspects of students' perception of school experience. There is no consensus over the definition of PSC, but it generally refers to students' perception of psychophysical characteristics of school climate (Sink \& Spencer, 2005). Recently, a formal and consistent definition of SC has been presented by NSCC (National School Climate Center) in 2007 that includes four backgrounds of school function: physical security, individuals' relationships at school such as teachers, employees and parents, educational methods and school physical environment (Sely, 2013). Therefore, according to NSCC (2007), SC refers to the life quality and character at school. SC is based on the experience models of life at school in students, parents and school personnel and reflects norms, objectives, values, interpersonal relationships teaching and learning activities as well as organizational structures. A resilient and positive SC nurtures students' development and their learning, which is indispensable for effective participation and life satisfaction in a democratic society. Thus, SC reflects the physical, psychological and social aspects of school and in fact, shows a feeling that learners acquire from their daily experience at school (Adomnick, 2012).

Various researches have shown the importance of positive school climate that includes supportive climate and mutual relations between students and teachers. According to NSCC (2007), security, confidence, respect, impartiality, high expectations and a pleasant climate are among the aspects of a positive climate at school. Students, teachers and parents' PSC leads to students' learning, academic achievement, school success, PYD and prevention of risky behaviors (Adamnick, 2012). The results of the research conducted by Bundick and Tirri (2014) concerning teacher support in goal-setting and PYD indicate students' perception of teacher support can predict their purposefulness and positive development. Moreover, Way 
et al., (2007) in a longitudinal study, analyzed the relation between students' PSC and behavioral-psychological adaptability from the sixth grade to the eight one. The research results indicated that all dimensions of PSC were reduced over the three years. Moreover, the results of one research conducted by Hejazi and Salehnajafi (2015) indicated a positive correlation between class perception and students' PYD.

\section{METHOD}

\section{Procedure}

The methodology of the current study and its research plan is descriptive (non-empirical) and the relation between variables is analyzed in the form of a regression model.

\section{Statistical Population and Sample}

The statistical population of the research includes all female high school students of Kerman studying in the academic year 2014-15. The size of the statistical population was estimated 3810 persons according to the report of SENAD system of the Educational Plan Department of Kerman that among them 400 persons were selected as the research sample. To select the participants in the research, multiphase clustering sampling method was used. To control the difference made by urban or non-urban effect in the research variable, the sampling was limited to the urban regular schools.

\section{Measures}

\section{POP}

Students' perception of parenting style was measured by the scale of the perception of parents prepared by Robbins (1994) and according to the theory of self-determinism. This scale has two versions of children and college students. In this research, the second version that is designed in accordance with the adolescent years is used. This scale has 42 items (21 items for the mother and 21 items for the father which are 21 items repeated twice, once for the mother and once for the father. Questions are adjusted based on the Liker five-point scale from completely disagree (1) to strongly agree (7). The factorial structure of this scale, according to the makers' view, includes the components of involvement, autonomy support and warmth for each of parents that totally constitutes six factors. The validity of the subscales of this tool by its makers is reported 0.72 and 0.86 (Robbins, 1994). The coefficients of Cronbach's alpha in the present research are $0.85,0.75,0.87,0.79,0.87,0.85$ and 0.93 for the subscales of involvement (mother), autonomy support (mother) warmth (mother), involvement (father), autonomy support (father) warmth (father), and the whole 
scale, respectively. The results of confirmatory factorial analysis are mentioned in Table 1.

\section{PSC}

To measure PSC, the questionnaire developed by Jia, Way, Ling, \& Yashikawa (2009) was used. This questionnaire has 25 items measuring three dimensions of teacher support (7 items), student support (13 items) autonomy support (5 items). The questions are scored based on Likert four points from 1 (almost always) to 5 (never). Cronbach's alpha coefficient in the present research is $0.89,0.92,0.70$ and 0.83 for teacher support, student support, and autonomy support and the whole scale, respectively.

\section{PYD}

PYD inventory (Arnold, Nott \& Meinhold, 2012) has two short and long forms that is prepared based on 5C model of PYD (Lerner et al., 2005). In the present research, the long from with 48 items and 5 subscales of competence (14 items), confidence (9 items), connection (8 items), character (9 items) and caring (8 items) was used. Questions are adjusted in the continuum form of 4 points from (1) completely disagree to (4) strongly agree. Alpha coefficients in the present research were obtained $0.78,0.85,0.87,0.83,0.85$ and 0.88 for competence, confidence, character, caring, connection and the whole scale, respectively

Table 1. Fitness indices of confirmatory factorial analysis models

\begin{tabular}{ccccccc}
\hline Indices & $\chi^{\mathbf{2} / \mathbf{d f}}$ & RMSEA & GFI & AGFI & CFI & NFI \\
\hline $\begin{array}{c}\text { Perception } \\
\text { of }\end{array}$ & 2.90 & 0.069 & 0.95 & 0.91 & 0.97 & 0.95 \\
parenting & & & & & & \\
\hline $\begin{array}{c}\text { Perception } \\
\text { of school } \\
\text { climate }\end{array}$ & 2.38 & 0.059 & 0.94 & 0.91 & 0.97 & 0.95 \\
\hline PYD & 2.69 & 0.065 & 0.93 & 0.90 & 0.96 & 0.95 \\
\hline
\end{tabular}

\section{RESULTS}

Descriptive indices (mean and standard deviation) and the correlative matrix of the research variables are presented in Table 2.

Table 2. Correlative matrix of research variables

\begin{tabular}{llllllllll}
\hline $\mathrm{N}$ & Variable & Mea & Standard & 1 & 2 & 3 & 4 & 5 & 6
\end{tabular}




\begin{tabular}{|c|c|c|c|c|c|c|c|c|c|}
\hline 0 & & $\mathrm{n}$ & $\begin{array}{c}\text { deviatio } \\
\mathrm{n}\end{array}$ & & & & & & \\
\hline 1 & $\begin{array}{l}\text { Teacher } \\
\text { support }\end{array}$ & 2.60 & 0.76 & 1 & & & & & \\
\hline 2 & $\begin{array}{l}\text { Autonomy } \\
\text { support }\end{array}$ & 2.86 & 0.78 & $\begin{array}{c}0.59 * \\
*\end{array}$ & 1 & & & & \\
\hline 3 & $\begin{array}{c}\text { Students' } \\
\text { support }\end{array}$ & 3.30 & 0.62 & $\begin{array}{c}0.27 * \\
*\end{array}$ & $\begin{array}{c}0.24 * \\
*\end{array}$ & 1 & & & \\
\hline 4 & $\begin{array}{c}\text { Parents' } \\
\text { autonomy }\end{array}$ & 3.28 & 0.87 & $\begin{array}{c}0.23 * \\
*\end{array}$ & $\begin{array}{c}0.18 * \\
*\end{array}$ & $\begin{array}{c}0.19 * \\
*\end{array}$ & 1 & & \\
\hline 5 & $\begin{array}{c}\text { Parents' } \\
\text { engagement }\end{array}$ & 3.22 & 0.74 & $\begin{array}{c}0.27 * \\
*\end{array}$ & $\begin{array}{c}0.23 * \\
*\end{array}$ & $\begin{array}{c}0.22 * \\
*\end{array}$ & $\begin{array}{c}0.57 * \\
*\end{array}$ & 1 & \\
\hline 6 & $\begin{array}{l}\text { Parents' } \\
\text { warmth }\end{array}$ & 3.43 & 0.76 & $\begin{array}{c}0.15^{*} \\
*\end{array}$ & $\begin{array}{c}0.13 * \\
*\end{array}$ & $\begin{array}{c}0.21 * \\
*\end{array}$ & $\begin{array}{c}0.39 * \\
*\end{array}$ & $\begin{array}{c}0.58 * \\
*\end{array}$ & 1 \\
\hline 7 & PYD & 2.76 & 0.65 & $\begin{array}{c}0.40 * \\
*\end{array}$ & $\begin{array}{c}0.32 * \\
*\end{array}$ & $\begin{array}{c}0.24 * \\
*\end{array}$ & $\begin{array}{c}0.45 * \\
*\end{array}$ & $\begin{array}{c}0.57 * \\
*\end{array}$ & $\begin{array}{c}0.33^{*} \\
*\end{array}$ \\
\hline
\end{tabular}

As shown in Table 2, the correlative coefficient of school climate dimensions namely teacher support $(\mathrm{r}=0.40)$, autonomy support $(\mathrm{r}=0.32)$ and students' support $(\mathrm{r}=0.24)$ are positively and significantly related to PYD at the $\mathrm{p}<0.01$ level. The correlative coefficient of parenting styles namely parents' autonomy $(r=0.45)$, parents' engagement $(r=0.57)$ and parents' warmth $(r=0.33)$ is positively and significantly related to PYD at the $\mathrm{p}<0.01$ level.

The stepwise regression was used to predict PYD from the variables of school climate dimensions and parenting styles.

In the regression analysis, PYD, teacher support and parents' autonomy were entered into the equation in the first, second and third steps, respectively. These three variables preserved their significance during the three steps, but autonomy support, students' support and parents' warmth were eliminated from the analysis owing to their insignificance. In Table 3, the regression results are presented. 
Table 3. Results of stepwise regression of PYD from school climate dimensions and parenting styles

\begin{tabular}{ccccccc}
$\begin{array}{c}\text { Entered } \\
\text { variables }\end{array}$ & $\mathrm{R}$ & $\mathrm{R}^{2}$ & $\begin{array}{c}\text { Adjusted } \\
\mathrm{R}^{2}\end{array}$ & $\begin{array}{c}\text { Standard } \\
\text { deviation }\end{array}$ & $\mathrm{R}^{2}$ & $\mathrm{~F}$ \\
\hline $\begin{array}{c}\text { Parents' } \\
\text { engagement }\end{array}$ & 0.567 & 0.321 & 0.319 & 0.53 & 0.321 & $188.261^{* *}$ \\
\hline $\begin{array}{c}\text { Teacher } \\
\text { support }\end{array}$ & 0.619 & 0.383 & 0.380 & 0.51 & 0.062 & $123.368^{* *}$ \\
\hline $\begin{array}{c}\text { Parents' } \\
\text { autonomy }\end{array}$ & 0.632 & 0.40 & 0.395 & 0.50 & 0.016 & $87.824^{* *}$ \\
\hline
\end{tabular}

As shown in Table 3, parents' engagement, teacher support and parents' autonomy explain 32.1, 6.2 and 1.6 of the changes of PYD, respectively. These three variable totally explain $40 \%$ of the changes of PYD. As shown in Table 3, the results of variance analysis indicate that parents' engagement, teacher support and parents' autonomy significantly affect PYD.

Table 4. Coefficients of stepwise regression of PYD from school climate dimensions and parenting styles

\begin{tabular}{ccccccc}
\hline $\begin{array}{c}\text { Entrance } \\
\text { degree of } \\
\text { variables }\end{array}$ & $\begin{array}{c}\text { Predicting } \\
\text { variable }\end{array}$ & $\begin{array}{c}\beta \\
\text { Standard } \\
\text { coefficients }\end{array}$ & $\begin{array}{c}\text { Standard } \\
\text { deviation }\end{array}$ & $\begin{array}{c}\text { Nonstandard } \\
\text { coefficients } \\
\text { B }\end{array}$ & t & $\begin{array}{c}\text { Significance } \\
\text { level }\end{array}$ \\
\hline First step & $\begin{array}{c}\text { Parents' } \\
\text { engagement }\end{array}$ & 0.567 & 0.036 & 0.496 & 13.721 & 0.001 \\
\hline & Parents' & 0.494 & 0.036 & 0.433 & 12.051 & 0.001 \\
\hline
\end{tabular}

Second engagement

\begin{tabular}{lllllll} 
step & $\begin{array}{l}\text { Teacher } \\
\text { support }\end{array}$ & 0.26 & 0.035 & 0.22 & 6.326 & 0.001 \\
& & & & & & \\
\hline & Parents' & 0.408 & 0.042 & 0.358 & 8.45 & 0.001
\end{tabular}

Third step engagement

\begin{tabular}{cccccc}
\hline $\begin{array}{c}\text { Teacher } \\
\text { support }\end{array}$ & 0.247 & 0.035 & 0.21 & 6.069 & 0.001 \\
\hline $\begin{array}{c}\text { Parents' } \\
\text { autonomy }\end{array}$ & 0.156 & 0.035 & 0.116 & 3.272 & 0.001 \\
\hline
\end{tabular}


As shown in Table 4, t-coefficients indicate that the effect of parents' engagement $(\beta=0.408)$, teacher support $(\beta=0.247)$ and parents' autonomy $(\beta=0.156)$ on PYD is positive and significant at the level 0.001 .

\section{DISCUSSION AND CONCLUSION}

The objective of the present research was to predict PYD based on POP and PSC. The results of Pearson correlation indicated a positive and significant correlation between school climate dimensions (teacher support, autonomy support and students' support), and PYD and a positive and significant correlation between POP dimensions (parents' engagement, warmth and autonomy support) and PYD. In this regard, it can be mentioned that children and adolescents do not grow invacuo so that new developmental theoreticians refer to "in-context development" and believe that the environments in which children are developed there paly a crucial role in their PYD. In addition, the results of stepwise regression indicated that parent engagement, teacher support and parent autonomy explain $40 \%$ of the changes of positive youth development. According to PYD, all adolescents have a number of capacities in their development path, but when adolescents' PYD is predictable that their biological and ecological resources and areas along with their development path have supportive and positive characteristics. Studies have indicated that as adolescents have more positive resources and the coordination between developmental levels and adolescents' biological resources is higher, their PYD is will be probably higher. Therefore, the existence of family, school and institutes supporting adolescents are as necessary as the existence of individual developmental capital (skills, talents and self-regulation) for adolescents' PYD (Zarrett \& Lerner, 2008).

According to the stepwise regression results, parents' engagement explains only $32.1 \%$ of the changes. In explaining, this finding, it can be mentioned that experiencing safe and stable relationships with parents and nurturing in a calm and disciplined atmosphere contribute the mental welfare and sociability, because children's development is highly affected by relationships with parents. Based on the theories of self-determinism, an environment that provides the background to meet basic psychological needs in individuals, increases internal inclination to individuals' health and psychological adaptability. Grolnick et al. (1997) also believe that individuals need to feel belonging to parents and feel security in their relationships with them. In this regard, according to Gonzalez-DeHass, Willems, \& Holbein. (2005), when parents are engaged in adolescents' academic activities at home as a trustable 
resource; adolescents feel competence and their background of PYD is provided. Therefore, parents who are sensitive to their children needs and are engaged in their children's academic affairs will meet belonging need in them by creating tranquility of mind that in turn, creates high levels of PYD.

Furthermore, stepwise regression results indicate that teacher support explains $6.2 \%$ of the changes of PYD. According to the theory of self-determinism, teachers and their behaviors are considered one of the contextual and social factors that significantly affects students' behavior, attitude, welfare and PYD. Students' relationships with teachers are the most important factor in students' understanding of positive school climate. If students feel that they and their security are supported and are actively participated in decision-making and planning for the class, it is perceived that they are worthy and capable in teacher's view. When teachers support students, students feel agency and consider themselves autonomic in starting, maintaining and regulating activities and think that they are the cause of their behavior and this issue meets their basic psychological needs and PYD. Ryan and Partrick (2001) have emphasized on the social environment of class, school and relationships between students and teachers. They, in their research, found that a supportive environment explains students' self-efficacy in making relationship with teacher, self-efficacy in completing school works, self-regulation learning and students' distressed behavior. Thus, perception of class atmosphere creates PYD in students by its effect on individuals' beliefs including the belief of self-worthiness.

Finally, parents' autonomy explains 1.6 of the changes of PYD. According to the view of developmental capital, all children, adolescents and youths need a set of positive structures to be successful that in this regard, developmental capital include important conventions, skills, opportunities and values that helps adolescents to be away from risky behaviors, increases their resilience and promote their prosperity. One of the components of the external dimension of developmental capital includes parents and receiving their support. Benson, Galbraith, \& Espeland (1998), Scales \& Leffert (1999), Scales \& Taccogna (2000) used the data of Minnesota Institute to indicate the effect of developmental capital on adolescents' life. As adolescents have higher developmental capital, they are less involved in risky behaviors such as violence, alcohol use, drug use, early sexual relationships and offenses. In explaining this result, according to Vallerand, Fortier, \& Guay (1997), it can be mentioned that if parents give opportunity to students to select their favorite activities freely and encourage them to participate in academic affairs, students will feel competency and autonomy and as a result, 
they report higher level of PYD.

The research results have applied implications. Planning and implementing each program are relevant to the promotion of adolescents' positive development that requires its identification of effective elements and components. The research results can be taken into account by planners and can make reforms in the educational institution

According to the relational developmental systems perspective, PYD is affected by individual and contextual factors. In the present research, the role of individual factors is not analyzed in predicting PYD. Thus, it is recommended that the role of both individual and contextual factors in predicting PYD will be analyzed in future researches. Furthermore, the research data have been collected using self-report tools. This kind of data is biased inadvertently and advertently, therefore, it is suggested that qualitative and mixed research methodologies be employed in future researches.

\section{REFERENCES}

[1] Adomnick, J. G. (2012). The effects of self-determination, identification with school, and school climate on middle school students' aspirations for future education. (Doctoral Dissertation). Retrieved from ProQuest Dissertations and Theses. (Accession Order No DAI-A 73/10(E).

[2] Arnold, M.E., Nott, B. D., \& Meinhold, J. L. (2012). The Positive Youth Development Inventory (Revised 2012). (C) Oregon State University.

[3] Benson, P. L. (1997). Spirituality and the adolescent journey. Reclaiming Children and Youth, 5(4), 206-209.

[4] Benson, P. L., Galbraith, J., \& Espeland, P. (1998). What Kids Need To Succeed: Proven, Practical Ways To Raise Good Kids.(Revised, Expanded. Free Spirit Publishing, 400 First Avenue North, Suite 616, Minneapolis, MN 55401-1724.

[5] Benson, P. L., Mannes, M., Pittman, K., \& Ferber, T. (2004). Youth development, developmental assets, and public policy. Handbook of Adolescent Psychology, Second Edition, 781-814.

[6] Bowers, E. P., Li, Y., Kiely, M. K., Brittian, A., Lerner, J. V., \& Lerner, R. M. (2010). The Five Cs Model of Positive Youth Development: A longitudinal analysis of confirmatory factor structure and measurement invariance. Journal of Youth and Adolescence, 39(7), 720-735.

[7] Bundick, M. J; \& Tirri, K. (2014). Student Perceptions of Teacher Support and 
Competencies for Fostering Youth Purpose and Positive Youth Development: Perspectives from Two Countries. Applied Developmental Science. Applied Developmental Science 18 (3), 148-162.

[8] Bundick, M. J., Yeager, D. S., King, P. E., \& Damon, W. (2010). Thriving across the lifespan. In R. M. Lerner, M. E. Lamb, A.M. Freund, \& W. F. Overton (Eds.), Handbook of life- span development, Vol. 1: Cognition, Biology and Methods (pp. 882-923). Hoboken, NJ: John Wiley \& Sons.

[9] Chand, N., Farruggia, S., Dittman, C., Ting Wai, J. C., \& Matthew, S. (2013). Promoting positive youth development through a brief parenting intervention program. Youth Studies Australia 32, 1, 29-36.

[10] Deci, E. L., \& Ryan, R. M. (1985). Intrinsic Motivation and self- determination in human behavior. New York: Plenum Press.

[11]Farruggia, S.P., \& Bullen, P. (2012). Positive youth development in Aotearoa/New Zealand, in Lifespan development: New Zealand perspectives, $2^{\text {nd }}$, eds J. Low \& P. Jose, Pearson, Auckland.

[12] Gonzalez-DeHass, A. R., Willems, P. P., \& Holbein, M. F. D. (2005). Examining the relationship between parental involvement and student motivation. Educational psychology review, 17(2), 99-123.

[13] Gootman, J. A., \& Eccles, J. (Eds.). (2002). Community programs to promote youth development. National Academies Press.

[14] Grolnick, W. S., Ryan, R. M. \& Deci, E. L. (1997). Internalization in the family: The self-determination perspective. In J. E. Grusec and L. Kuczynski (Eds.) Parenting and children's internalization of values. NY: Wiley.

[15] Hejazi, E., Saleh Najafi, M., \& Gholamali Lavasani, M. (2015). Perception of Classroom Environment, Optimism and their Relationships with Positive Students Development. Journal of Psychology. 19(2), 188-198.

[16] Jia, Y; Way, N; Ling, G; Yashikawa, H., (2009). The Influence of Student Perceptions of School Climate on Socioemotional and Academic Adjustment: A Comparison of Chinese and American Adolescents. Child Development, 80, 5, 1514-1530.

[17] Kerr, M., \& Stattin, H. (2000). What parents know how they know it, and several forms of adolescent adjustment: further support for a reinterpretation of monitoring. Developmental psychology, 36(3), 366.

[18] Lerner, R. M. (2004). Liberty: Thriving and civic engagement among America's youth. 
Thousand Oaks, CA: Sage.

[19]Lerner, R. M., \& Benson, P. (2003). Developmental assets and asset-building communities: Implications for research, policy, and practice (Vol. 1). Springer Science \& Business Media.

[20] Lerner, R. M., Dowling, E. M., \& Anderson, P. M. (2003). Positive youth development: Thriving as a basis of personhood and civil society. Applied Developmental Science, 7 , 172-180.

[21]Lerner, R. M., Lerner, J. V., Almerigi, J. B., Theokas, C., Gestsdottir, S., Naudeau, S., et al. (2005). Positive youth development, participation in community youth development programs and community contributions of fi fth-grade adolescents: Findings from the fi rst wave of the 4-H study of positive youth development. Journal of EarlyAdolescence, 25(1), 17-71.

[22] Lerner, R. M., Lerner, J. V., Bowers, E. P., Lewin-Bizan, S., Gestsdottir, S., \& Urban, J. B. (2011). Self-regulation processes and thriving and in childhood and adolescence: A view of the issues. New Directions for Child and Adolescent Development, 133, 1-9.

[23] McElhaney, K. B., Allen, J. P., Stephenson, J. C., \& Hare, A. L. (2009). Attachment and autonomy during adolescence. Handbook of adolescent psychology.

[24] Nash, S. G., McQueen, A., \& Bray, J. H. (2005). Pathways to adolescent alcohol use: Family environment, peer influence, and parental expectations. Journal of Adolescent Health, 37(1), 19-28.

[25] Roth, J. L., \& Brooks-Gunn, J. (2003). What exactly is a youth development program? Answers from research and practice. Applied Developmental Science, 7(2), 94-111.

[26]Ryan, A. M. \& Patrick, M. (2001). Adolescents' motivation and engagement during middle school. American Educational Research Journal, 38, 2, 437-460.

[27]Ryan, R. \& Deci, E. 1. (2000). Self -determination theory and facilitation of intrinsic motivation, social development, and well- being. American psychologist: 55: 68- 78.

[28] Scales, P. C., \& Leffert, N. (1999). Developmental assets: A synthesis of the scientific research on adolescent development. Search Institute.

[29] Scales, P. C., \& Taccogna, J. (2000). Caring to try: How building students' developmental assets can promote school engagement and success. NASSP Bulletin, 84(619), 69-78.

[30] Sely, K, J. (2013).The Relationship between Middle School Climate and Student Mathematics Achievement. (Doctoral Dissertation). Retrieved from ProQuest 
Dissertations and Theses. (Accession Order DAI-A 73/10(E).

[31] Shaffer, D., \& Kipp, K. (2013). Developmental psychology: Childhood and adolescence. Cengage Learning.

[32] Sink, C. A., \& Spencer, L. R. (2005). My Class Inventory-Short Form as an accountability tool for elementary school counselors to measure classroom climate. Professional School Counseling, 9, 37-48.

[33] Vallerand, R. J., Fortier, M. S., \& Guay, F. (1997). Self-determination and persistence in a real-life setting: toward a motivational model of high school dropout. Journal of Personality and Social psychology, 72(5), 1161.

[34] Way, N; Reddy, R; \& Rhodes. (2007).Students' Perceptions of School Climate during the Middle School Years: Associations with Trajectories of Psychological and Behavioral Adjustment. Am J Community Psychol. 40, 194-213.

[35] West-Olatunji, C., Sanders, T., Mehta, S., \& Behar-horenstein, L. (2010). Parenting Practices among Low-income Parents/Guardians of Academically Successful Fifth Grade African American Children. Multicultural Perspectives, 12, 3, 138-144.

[36]Zarrett, N., \& Lerner, R. M. (2008). Ways to promote the positive development of children and youth. Child Trends Research-to-Results Brief.11.65-72.

\section{How to cite this article:}

Bakhshee F, Hejazi E, Dortaj F and Farzad V. Perceived parenting, school climate and positive youth development: a predicting model. J. Fundam. Appl. Sci., 2016, 8(3S), 654-667. 